\title{
FAKTOR - FAKTOR YANG MEMPENGARUHI EARLY MENARCHE PADA SISWI SEKOLAH DASAR KELURAHAN LAPADDE KOTA PAREPARE
}

\author{
Factors Affecting Early Menarhe in Elementary School Students in Lapadde Village Parepare \\ City
}

Devi Partika Sari, Nurhapsa, Erna Magga, Nurlinda

(Program Studi Kesehatan Masyarakat Fakultas Ilmu Kesehatan Universitas Muhamma diyah Parepare)

\begin{abstract}
ABSTRAK
Remaja adalah masa peralihan diantara masa kanak-kanak dan dewasa. Dalam masa ini anak mengalami masa pertumbuhan dan masa perkembangan fisiknya maupun perkembangan psikisnya. Adapun faktor- faktor yang mengakibatkan terjadinya early menarche yaitu lingkungan, status ekonomi dan status gizi. Penelitian ini menggunakan Accidental Sampling. Lokasi penelitian di lakukan di 6 sekolah yang terdapat di Kelurahan Lapadde. Adapun waktu penelitian dilakukan pada bulan Mei s/d Juli 2018. Populasinya adalah semua siswi kelas 5 dan 6 di masing-masing sekolah yang berada di Kelurahan Lapadde, pengambilan sampel dilakukan dengan cara Purposive Sampling dengan jumlah sampel 61 siswi. Data dianalisis dengan uji Chi Square, koefisien phi dengan $\alpha 0,05$. Berdasarkan hasil uji chi-square menunjukkan bahwa ada pengaruh lingkungan terhadap early menarche siswi Sekolah Dasar $\mathrm{X}^{2}$ hit. 35,397 karena sebagian besar diakibatkan pergaulan yang cukup bebas dimana siswi dipengaruhi oleh media massa,ada pengaruh status ekonomi terhadap early menarche siswi Sekolah Dasar dengan $\mathrm{X}^{2}$ hit. 22,263 Penghasilan atau status ekonomi orang tua mempengaruhi kecukupan orang tua dalam memenuhi kebutuhan keluarga,dan ada pengaruh status gizi terhadap early menarche siswi Sekolah Dasar dengan $\mathrm{X}^{2}$ hit. 8,780 bahwa keadaan status gizi yang normal dan keadaan status gizi yang tidak normal atau obesitas itu mempengaruhi terjadinya erlay menarche karena asupan gizi yang kurang menyebabkan gizi pada seseorang akan berdampak pada penurunan fungsi reproduksi.
\end{abstract}

Kata kunci : Lingkungan, status ekonomi, status gizi, early menarche

\begin{abstract}
Teenagers are a transitional period between childhood and adulthood. During this time the child experiences a period of growth and a period of physical development and psychological development. The factors that lead to early menarche are environment, economic status and nutritional status. This study uses Accidental samplin. Research locations were conducted in 6 schools located in Lapadde. This study was conducted from May to July 2018. The population was students in the fifth grade and in each school located in Lapadde, sampling was done by purposive sampling with a sample of 61 female students. Data were analyzed by Chi Square test, coefficient of phi with a 0.05. Based on the results of the chi-square test shows that there is an environmental influence on early menarche of elementary school students X hit. 35,397 because most of it is caused by quite free association where students are influenced by mass media, there is an influence of economic status on early menarche of elementary school students with X2 hit.
\end{abstract}


22,263 Parental income or economic status affects the adequacy of parents in meeting family needs, from the influence of nutritional status on early menarche of elementary school students with X2 hit. 8,780 that the state of normal nutritional status and the condition of abnormal nutritional status or obesity that affect the occurrence of erlay menarche because nutrient intake that causes less nutrition in a person will have an impact on the decline in reproductive function.

Keywords: Environment, economic status, nutritional status, early menarche 


\section{PENDAHULUAN}

Remaja adalah masa peralihan diantara masa kanak-kanak dan dewasa. Dalam masa ini anak mengalami masa pertumbuhan dan masa perkembangan fisiknya maupun perkembangan psikisnya. Mereka bukanlah anak-anak baik bentuk badan ataupun cara berfikir atau bertindak, tetapi bukan pula orang dewasa yang telah matang. Pada masa remaja ini terjadi pubertas dalam diri seseorang anak (perempuan maupun laki-laki) salah satu tanda perempuan mengalami pubertas adalah terjadinya menarche. Menarche merupakan menstruasi pertama kali yang ditandai dengan keluarnya darah dari vagina akibat peluruhan dinding endometrium. ${ }^{1}$

Membaiknya standar kehidupan terutama faktor asupan makanan dan genetik akan berdampak pada usia menarche dini menstruasi pertama yang terjadi lebih awal atau lebih cepat dari kebiasaan yang berlaku secara umum di tengah-tengah masyarakat tersebut. Faktor rendahnya asupan serat dan tingginya asupan lemak maupun kalsium berdampak pada usia menarche dini. Sebelum memasuki masa remaja, seseorang akan mengalami periode pubertaster lebih dahulu. Pada periode pubertas inilah akan terjadi percepatan pertumbuhan dan perkembangan fisik dari anak-anak menjadi dewasa serta mengalami kematangan organ reproduksi seksual. Menarche merupakan menstruasi yang pertama kali dialami wanita, dimana secara fisik ditandai dengan keluarnya darah dari vagina akibat peluruhan lapisan endometrium. Usia menarche bervariasi dari rentang umur 10-16 tahun, akan tetapi usia menarche dapat dikatakan normal apabila terjadi pada usia 12-14 tahun. ${ }^{2}$

Menurut World Health

Organization (2015) sekitar seperlima dari penduduk dunia remaja berusia 1019 tahun. Sekitar 900 juta berada di negara sedang berkembang yang mengakibatkan cepatnya mengalami menarche pada anak remaja. Sedangkan $85 \%$ diantaranya hidup di negara berkembang. Prevalansi early menarche berbeda-beda disetiap negara,seperti Kanada anak yang mengalami early menarche sebesar 14,6\% dan di bagian Asia seperti di China 10\% anak perempuan mengalami early menarche. Early menarche yang terjadi di Negaranegara seperti di Amerika dan Eropa meningkatkan kebutuhan untuk menggali informasi mengenai kejadian early menarche di Negara-negara lain, termasuk Indonesia menduduki peringkat 
ke-15 dari 67 negara dengan percepatan usia menarche yang mencapai 0,145 tahun perdekade. Walupun demikian usia rata-rata anak yang mengalami menarche dari Negara-negara lain yaitu 12-14 tahun. ${ }^{3}$

Hasil Riskesdas

menunjukan bahwa berdasarkan laporan responden yang sudah mengalam haid rata-rata usia menarche di Indonesia 13 tahun (20\%) dengan kejadian lebih awal pada usia kurang dari 9 tahun. Secara nasional rata - rata usia menarche13-14 tahun terjadi pada 37,5\% anak Indonesia dan ada juga yang baru berusia 8 tahun sudah memulai siklus haid namun jumlah ini sedikit sekali. Bahwa dari 400 pelajar putri Bugis kota di Sulawesi Selatan yang sudah menarche berusia antara 10 tahun sampai 15 tahun. Hal ini meliputi kelompok kota 200 orang dengan usia rata-rata 13 tahun, sehingga disimpulkan bahwa ditemukan perbedaan berat badan, status gizi, status sosial ekonomi dan aktifitas fisik responden terhadap pencapaian usia menarche pada pelajar Bugis kota dan desa di Sulawesi Selatan.

Penelitian terbaru menunjukan bahwa ada kecenderungan penurunan usia menarche. Faktor yang dianggap mempercepat menarche adalah adanya perbaikan gizi, latar belakang status ekonomi keluarga dan faktor keturunan. Indonesia sendiri menempati urutan ke15 dari 67 negara dengan penurunan umur menarche mencapai 0,145 tahun per dekade. Umur menarche pada perempuan dapat lebih awal atau lebih lambat juga dipengaruhi oleh beberapa faktor, salah satu diantaranya yaitu status gizi. $^{2}$

Berdasarkan hasil penelitian yang di SMA Makassar tentang hubungan status gizi dan usia pada menarche menyimpulkan adanya hubungan status gizi dan usia menarche pada remaja. Dimana hasil pengolahan datanya memperlihatkan adanya variasi pada usia menarche responden bahwa sekitar 36,7 $\%$ yang lebih cepat terkena menarche dan yang termaksud ideal sekitar 63,3\% hal ini menunjukka bahwa masih banyak anak remaja yang mengalami menarche lebih awal. ${ }^{5}$

Adapun faktor-faktor yang menyebabkan Erlay Menarche sesuai dengan observasi awal yang dilakukan oleh peniliti di Kota Pare-Pare yaitu Pertama lingkungan yang dimksud disini gaya hidup dimana pergaulan anak SD dari lokasi penelitian tersebut sangat memprihatinkan karena sebagian besar cukup bebas dan adanya media massa yang memicu akan pergulan anak yang bisa menyebabkan pubertas dini 


\begin{abstract}
Kedua pendapatan keluarga (status ekonomi) Erlay Menarche terlambat terjadi pada kelompok sosial ekonomi sedang sampai tinggi yang memiliki selisih sekitar 12 bulan. Orang yang berasal dari keluarga yang biasa mengalami menarche lebih dini. Namun setelah diteliti lebih lanjut asupan protein lebih berpengaruh terhadap kejadian menarche yang lebih awal.
\end{abstract}

Ketiga faktor status gizi disini dimaksud adalah merupakan keadaan kesehatan akibat interaksi antara makanan, tubuh manusia dan lingkungan hidup manusia. Selanjutnya, Mc. Laren menyatakan bahwa status gizi merupakan hasil keseimbangan antara zat-zat gizi yang masuk dalam tubuh manusia dan penggunaannya status gizi ini sangatlah penting karena kekurangan ataupun kelebihan gizi bisa menyebabkan timbulnya penyakitpenyakit tertentu sesuai degan survei awal yang dilakukan oleh peneliti keadaan status gizi pada siswi SD di lokasi penelitian cukup menjadi perhatian adapun yang mengalami status gizi yang kurang baik itu diakibatkan oleh pola makan yang kurang baik dan jajan siap saji. Makanan yang bergizi tinggi dan berlemak tinggi dan berasal dari hewani akan mengakibatkan pertumbuhan berat badan pada perempuan remaja. Kadar estrogen akan meningkat akibat kolesterol tinggi. Bukan hanya lemak dari komposisi tubuh saja tetapi sebaliknya dipengaruhi oleh faktor asupan makan dan faktor tidak adanya penyakit yang melemahkan. Suatu hal yang dapat mempengaruhi pembentukan hormone salah satunya adalah asupan gizi, dengan asupan gizi yang baik dapat mempercepat pembentukan hormone-hormon yang mempengaruhi datangnya menarche.

Berdasarkan dari hasil observasi siswi sekolah dasar yang mengalami early menarche di Kecematan Ujung yang peneliti berpusat pada sekolah dasar yang ada di Kelurahan Lapadde Kota Pare-Pare yang ternyata di era yang semakin tahun semakin modern dan pergaulan para remaja pun yang semakin bebas yang mengakibatkan terjadinya menarche yang lebih awal sekitar $42 \%$ siswi yang masih kategori sangat muda dibawa umur 10 tahun.

Adapun faktor-faktor yang
mempengaruhi early menarche pada
siswi sekolah dasar di Kelurahan
Lapadde Kota Parepare, yaitu
lingkungan,status ekonomi dan status
gizi, karena status gizi dinilai dengan
indeks masa tubuh yang beresiko


terjadinya penyakit saat dewasa. Inilah yang menjadi alasan peneliti untuk mengangkat judul "Faktor-faktor yang Mempengaruhi Early Menarche pada Siswi Sekolah Dasar di Kelurahan Lapadde Kota Parepare” .

Berdasarkan uraian-uraian pada latar belakang di atas untuk memberikan masukan-masukan yang lebih baik mengenai kesehatan dan terutama mengenai pergaulan yang baik untuk para remaja dan agar penelitian ini lebih terarah serta mencapai sasaran yang diharapkan, maka dirumuskan beberapa masalah yaitu sebagai berikut : "Adakah pengaruh faktor lingkungan terhadap early menarche pada Siswi Sekolah Dasar di Kelurahan Lapadde Kota Parepare", "Adakah pengaruh status ekonomi keluarga terhadap early menarche pada Siswi Sekolah Dasar di Kelurahan Lapadde Kota Parepare" dan "Adakah pengaruh status gizi terhadap early menarche pada Siswi Sekolah Dasar di Kelurahan Lapadde Kota Parepare"

Tujuan penelitian ini adalah untuk mengetahui adakah pengaruh faktor lingkungan terhadap early menarche pada Siswi Sekolah Dasar di Kelurahan Lapadde Kota Parepare, untuk mengetahui adakah pengaruh status ekonomi keluarga terhadap early menarche pada Siswi Sekolah Dasar di Kelurahan Lapadde Kota Parepare dan untuk mengetahui adakah pengaruh status gizi terhadap early menarche pada Siswi Sekolah Dasar di Kelurahan Lapadde Kota Parepare.

\section{BAHAN DAN METODE}

Desain penelitian ini menggunakan metode penelitian observasional analitik dengan pendekatan cross sectional. Populasi dalam penelitian ini sebanyak 159 siswi. Penelitian ini menggunakan Accidental Sampling. Variabel independen dalam penelitian ini adalah faktor lingkungan, status ekonomi keluarga dan statu gizi sedangkan variabel dependen adalah Early Menache pada siswa SD. Berdasarkan hasil uji Chi Kuadrat, diperoleh nilai $\mathrm{X}^{2}$ hitung = 35,397dan $\quad X^{2}$ tabel $=3,841$ dengan taraf signifikan 5\%. Karena $\mathrm{X}^{2}$ hitung $>\mathrm{X}^{2}$ tabel, ini berarti Ho ditolak, nilai $\mathrm{X}^{2}$ hitung = 22,263 dan $X^{2}$ tabel $=5,991$ dengan taraf signifikan $5 \%$. Karena $X^{2}$ hitung $>X^{2}$ tabel Ho ditolak. Dan nilai $\mathrm{X}^{2}$ hitung $=8,780$ dan $X^{2}$ tabel $=5,991$ dengan taraf signifikan 5\%. Karena $X^{2}$ hitung $>X^{2}$ tabel, ini berarti Ha diterima dan Ho ditolak. Artinya ada pengaruh yang signifikan antara status gizi terhadap siswi sekolah dasar yang mengalami early menarche.

\section{HASIL}

Karakteristik responden pada penelitian ini dapat digambarkan pada Tabel 1. Responden berjumlah 61 siswi sekolah dasar di Kelurahan Lapadde Kota Parepare, Tabel tersebut memperlihatkan hasil tertinggi umur responden adalah $9-11$ tahun dimana terdapat 37,7\% Responden dan umur responden 11 -13 tahun sebanyak $62,3 \%$. 
Berdasarkan hasil uji Chi Kuadrat, diperoleh nilai $\mathrm{X}^{2}$ hitung $=35,397$ dan $\quad X^{2}$ tabel $=3,841$ dengan taraf signifikan 5\% Karena $X^{2}$ hitung $>X^{2}$ tabel, ini berarti Ha diterima dan Ho ditolak. Artinya ada pengaruh yang signifikan antara faktor lingkungan terhadap siswi sekolah dasar yang mengalami early menarche.

Berdasarkan hasil penelitian yang dilakukan di Kelurahan Lapadde terhadap 61 responden, maka ditemukan pengaruh status ekonomi terhadap early menarche pada siswi sekolah dasar seperti yang dapat dilihat pada Tabel 2. Data pada Tabel 2 diketahui bahwa faktor status ekonomi yang tinggi terhadap early menarche sebanyak 9 siswi (14,8\%) dimana sebanyak 3 siswi (5\%) yang mengalami early menarche cepat dan yang mengalami early menarche lambat sebanyak 6 siswi (9,8\%), status ekonomi yang sedang terhadap early menarche sebanyak 38 siswi $(62,2 \%)$ dimana sebanyak 8 siswi (13\%) yang mengalami early menarche cepat dan yang mengalami early menarche lambat sebanyak 30 siswi $(49,2 \%)$, sedangkan status ekonomi yang rendah terhadap early menarche sebanyak 14 siswi (23\%) dimana sebanyak 13 siswi (21,3\%) yang mengalami early menarche cepat dan yang mengalami early menarche lambat sebanyak 1 siswi (1,7\%).

Berdasarkan hasil uji Chi Kuadrat, diperoleh nilai $X^{2}$ hitung $=22,263$ dan $X^{2}$ tabel $=5,991$ dengan taraf signifikan $5 \%$. Karena $X^{2}$ hitung $>X^{2}$ tabel, ini berarti Ha diterima dan Ho ditolak. Artinya ada pengaruh yang signifikan antara status ekonomi terhadap siswi sekolah dasar yang mengalami early menarche.

Berdasarkan hasil penelitian yang dilakukan di Kelurahan Lapadde terhadap 61 responden, maka ditemukan pengaruh status gizi terhadap siswi sekolah dasar yang mengalami early menarche seperti yang dapat dilihat pada Tabel 3. Data pada Tabel 3 diketahui bahwa faktor status gizi yang kurus terhadap early menarche sebanyak 12 siswi $(19,7 \%)$ dimana sebanyak 5 siswi $(8,20 \%)$ yang mengalami early menarche cepat dan yang mengalami early menarche lambat sebanyak 7 siswi (11,5\%), status gizi yang normal terhadap early menarche sebanyak 44 siswi $(72,1 \%)$ dimana sebanyak 14 siswi (22,9\%) yang mengalami early menarche cepat dan yang mengalami early menarche lambat sebanyak 30 siswi $(49,2 \%)$, sedangkan status gizi yang obesitas terhadap early menarche sebanyak 5 siswi $(8,20 \%)$ dimana sebanyak 5 siswi $(8,20 \%)$ yang mengalami early menarche cepat dan yang mengalami early menarche lambat tidak ada siswi (0\%).

Berdasarkan hasil penelitian yang dilakukan di Kelurahan Lapadde terhadap 61 responden, maka ditemukan pengaruh status gizi terhadap siswi sekolah dasar yang mengalami early menarche seperti yang dapat dilihat pada Tabel 4. Data pada Tabel 4 diketahui bahwa faktor status gizi yang kurus terhadap early menarche sebanyak 12 
siswi (19,7\%) dimana sebanyak 5 siswi $(8,20 \%)$ yang mengalami early menarche cepat dan yang mengalami early menarche lambat sebanyak 7 siswi (11,5\%), status gizi yang normal terhadap early menarche sebanyak 44 siswi $(72,1 \%)$ dimana sebanyak 14 siswi (22,9\%) yang mengalami early menarche cepat dan yang mengalami early menarche lambat sebanyak 30 siswi $(49,2 \%)$, sedangkan status gizi yang obesitas terhadap early menarche sebanyak 5 siswi $(8,20 \%)$ dimana sebanyak 5 siswi $(8,20 \%)$ yang mengalami early menarche cepat dan yang mengalami early menarche lambat tidak ada siswi (0\%).

Berdasarkan hasil uji Chi Kuadrat, diperoleh nilai $\mathrm{X}^{2}$ hitung $=8,780$ dan $\mathrm{X}^{2}$ tabel $=5,991$ dengan taraf signifikan 5\% Karena $\mathrm{X}^{2}$ hitung $>\mathrm{X}^{2}$ tabel, ini berarti Ha diterima dan Ho ditolak. Artinya ada pengaruh yang signifikan antara status gizi terhadap siswi sekolah dasar yang mengalami early menarche.

\section{PEMBAHASAN}

Berdasarkan hasil penelitian yang diperoleh maka ditemukan adanya pengaruh yang signifikan antara faktor lingkungan terhadap early menarche pada siswi sekolah dasar. Hal ini dapat dilihat Berdasarkan hasil uji Chi Kuadrat, dari tabel 10. diperoleh nilai $X^{2}$ hitung $=35,397$ dan $\quad X^{2}$ tabel $=$ 3,841 dengan taraf signifikan 5\%. Karena $\mathrm{X}^{2}$ hitung $>\mathrm{X}^{2}$ tabel, ini berarti Ha diterima dan Ho ditolak. Ini artinya ada pengaruh faktor lingkungan terhadap siswi sekolah dasar yang mengalami early menarche.

Berdasarkan dari hasil penelitian pengaruh faktor lingkungan terhadap early menarche pada siswi sekolah dasar sebanyak $39,3 \%$ siswi yang dipengaruhi dengan lingkungan hidup. Hal ini berdasarkan dari hasil observasi dan wawncara langsung serta hasil dari kousioner yang diberikan kepada siswi bahwa pergaulan siswi tersebut harusnya menjadi perhatian diakibatkan pergaulan bebas dimana siswi dipengaruhi oleh media sosial yang memicu siswi pernah melihat, menonton dan membaca majalah porno, melihat film porno baik itu di $\mathrm{Tv}$ maupun di internet, adapula yang sudah saling suka antara lawan jenisnya (pacaran), dan keluar malam dengan alasan ingin mengerjakan tugas sekolah padahal tidak semua siswi jujur akan hal itu. Hal ini tentu memicu pubertas dini pada siswi tersebut yang tentu saja mempengaruhi perkembangan fisikologis dan fisik siswi tersebut. Pergaulan kota dan didesa itu sangatlah berbeda dengan adanya perbedaan tersebut, seorang remaja memperoleh stimulus atau respon yang berbeda pula yang menyebabkan suatu proses kedewasaan atau pubertas yang lebih cepat.

Masa remaja mempunyai keingintahuan yang tinggi, belum sepenuhnya memiliki pertimbangan yang matang, mudah terombang-ambing, mudah terpengaruh, nekat dan berani, emosi tinggi dan tak mau ketinggalan. Masa remaja merupakan masa yang indah. Dan masa 
remaja tidak berlangsung lama. Maka dari itu, banyak para remaja yang memanfaatkan masa remaja mereka dengan berbagai hal yang menarik dan menantang. Maka, tidak luput pulalah remaja terkena masalah yang berbahaya. Hal itu karena kurangnya perhatian orang sehingga menjadi faktor terbesar dari remaja. Mereka tidak mendapat kebahagiaan dari lingkungan keluarga, maka mereka cenderung memilih mencari kebahagiaan diluar untuk menghilangkan masalah yang mereka hadapi.

Perbandingan anak perempuan yang tinggal diperkotaan dengan keadaan sosial dan gaya hidup yang sangat kompleks kemungkinan bahwa dia akan mengalami menarche lebih cepat dibanding perempuan yang tinggal dipedesaan. Hal tersebut dipengaruhi oleh gaya hidup, seperti dengan adanya program KB maka memperkecil jumlah anggota keluarga mendapatkan gizi yang baik.

Peran orang tua sangat besar dalam mempengaruhi usia menarche anak , misalnya ibu dengan semakin tingginya pendidikan ibu maka semakin tinggi pula pengetahuan ibu bagaimana cara mendidik dan memberikan arahan untuk anaknya mengenai pengetahuan hal ini berkaitan dengan kondisi pisikologis yang secara tidak sengaja dirasakan oleh anak khususnya perempuan pada masa tumbuh kembangnya. Perempuan khususnya yang sedang mengalami menarche awal berdampak pada fisikologisnya. Apabila peran orang tua terutama ibu kurang dalam memberikan pengetahuan tentang menstruasi dan perubahan-perubahan yang akan terjadi pada fisik si anak. Anak akan mengalami stres dan emosi yang lebih (kurang terkontrol dengan baik), cenderung pengetahuan tentang menstruasi sebaiknya dijelaskanoleh si ibu ataupun pihak sekolah jika menjumpai anak perempuan yang memiliki ciri-ciri fisik pada dirinya agar anak tidak merasakan shock ataupun khawatir saat mengalami menarche.

Sejalan dengan penelitian yang dilakukan oleh Priharyanti Wulandari (2015) di SMPN 31 Semarang didapatkan hasil kejadian menarche siswi berdasarkan uji kolrelasi rank spearman didapatkan hasil $n$ value $0,000<0,05$, dan rho hitung 0,824, Ha diterima da Ho ditolak, artinya ada hubungan terhadap faktor lingkungan dengan kejadian menarche. Penelitian tersebut tidak sejalan dengan penelitian yang dilakukan oleh Jemadi (2014) di SMP Swasta Harapan 1 dan 2 Medan dengan analisis statistik dengan menggunakan uji chi square diperoleh nilai $\mathrm{p}=0,243$ bahwa tidak terdapat hubungan yang bermakna antara lingkungan dengan kejadian menarche pada sisiwi. ${ }^{6}$

Berdasarkan hasil penelitian yang diperoleh maka ditemukan adanya pengaruh yang signifikan antara faktor status ekonomi terhadap early menarche pada sisiwi sekolah dasar. Hal ini dapat dilihat Berdasarkan hasil uji Chi Kuadrat, dari Tabel.11 diperoleh 
nilai $\mathrm{X}^{2}$ hitung $=22,263$ dan $\quad \mathrm{X}^{2}$ tabel $=$ 5,991 dengan taraf signifikan 5\%. Karena $\mathrm{X}^{2}$ hitung $>X^{2}$ tabel, ini berarti Ha diterima dan Ho ditolak. Ini artinya ada pengaruh faktor status ekonomi terhadap siswi sekolah dasar yang mengalami early menarche.

Pendapatan keluarga merupakan dengan upaya untuk mencukupi kebutuhan keluarga. Berdasarkan hasil uji statistik menyatakan bahwa ada pengaruh yang bermakna antara status ekonomi dengan kejadian erlay menarche terhadap sisiwi Sekolah Dasar di Kelurahan Lapadde.

Hasil penelitian menunjukkan bahwa erlay menarche tidak normal atau lambat lebih banyak dialami siswi yang pendapatan keluarganya < Rp.1.500.000, sampai Rp.1.500.000 yang bisa dikatakan jauh dari UMK dan erlay menarche yang normal pada siswi rata-rata pendapatan keluarganya > Rp.2.647.676, _ tentu saja hal ini menunjukkan bahwa pendapan keluarga itu berpengaruh pada kejadian erlay menarche pada siswi karena taraf hidup atau pendapatan yang cukup atau tinggi mempermudah orang tua memenuhi kebutuhan anak. Sedangkan orang tua yang memiliki pendapatan yang relatif rendah pada umumnya sulit untuk memenuhi segala kebutuhan.

Berdasarkan penelitian yang
dilakukan bahwa status ekonomi
mempengaruhi erlay menarche karena
keluarga mempunyai peran penting yang
cukup tinggi dalam hal percepatan umur
menarche saat ini. Hal ini berhubungan
menarche saat ini. Hal ini berhubungan karena tingkat sosial ekonomi pada suatu keluarga didalam hal kecukupan gizi keluarga terutama gizi anak perempuan dalam keluarga yang dapat mempengaruhi usia menarchenya. Hal ini dpat dilihat dari hasil penelitian bahwa status ekonomi yang tinggi menunjukkan $14,8 \%$ dan status ekonomi yang sedang menunjukkan $62,2 \%$ yang mengalami erlay menarche sedangkan tingkat ekonomi yang rendah sebanyak $23 \%$. Tentu saja orang tua yang memiliki penghasilan yang tinggi dapat memenuhi kebutuhan anak dan memberikan gizi yang baik. Tingkat sosial ekonomi dalam keluarga meliputi keluarga dan sumber-sumber yang dapat meningkatkan taraf hidup semua kelurga. Makin banyak jumlah uang yang diperoleh dan makin besar sumber-sumber yang dapat digali untuk meningkatkan taraf hidup anggota keluarga.

Penghasilan orang tua berhubungan dengan lingkungan hidup dan kondisi pisikologis anak yang mengalami masamasa pubertas, dengan penghasilan orang tua yang tinggi akan meningkatkan daya beli dalam kehidupan sehari-hari anak. Berdasarkan dari hasil penelitian dan observasi awal pada lokasi penelitian, anak dengan kondisi keadaan sosial ekonomi orang tua yang tinggi akan terpenuhi kebutuhan sehari-hari seperti fasilitas akses informasi media cetak, makanan yang bergizi, kebanyakan menkomsumsi makanan fast food, minuman soft drink sehingga remaja lebih terbuka dalam memperoleh informasi. Makanan fast food banyak 
mengandung pemanis buatan, lemak, dan zat aditif sehinggan membuat menarche datang lebih awal karena mengandung kalori yang lebih tinggi begitupun apabila mengkomsumsi soft drink. Selain status gizi yang mempengaruhi usia menarche antara lain adanya perubahan hormon yang mempengaruhi kematangan sel dan asupan gizi yang dikomsumsi saat menjelang datangnya menarche. Makanan yang bergizi dan berlemak tinggi dan berasal dari hewani akan mengakibatkan pertumbuhan berat badan pada perempuan, suatu hal yang dapat mempengaruhi pembentukan hormonhormon yang mempengaruhi datanganya menarche. Sehingga dengan perbaikan gizi yang baik dapat menyebabkan umur haid pertama lebih dini.

Penghasilan atau status ekonomi orang tua mempengaruhi kecukupan orang tua dalam memenuhi kebutuhan keluarga. Semakin tinggi penghasilan orang tua semakin banyak kebutuhan dan fasilitas yang diberikan kepada anak berbeda dengan pengasilan orang tua yang kurang tentu saja pemenuhan kebutuhan dan fasilitas anak sangat terbatas sehingga mempengaruhi informasi dan fasilitas yang diberikan kepada anak. Orang tua yang memiliki penghasilan cukup bisa memenuhi kebutuhan anak khususnya kebutuhan gizi dan informasi yang baik, berbeda dengan kebutuhan orang tua yang terbatas hanya bisa memenuhi kebutuhan gizi dan informasi yang seadanya. Kecukupan dan kekurangan konsumsi makanan pada anak mempengaruhi kematangan seksual memperlambat ataupun mempercepat kematangan seksual jadi remaja perlu mendapatkan nutrisi yang baik . Faktor yang berasal dari lingkungan seperti sosial ekonomi dan budaya mampu memacu maupun memperlambat usia menarche. Hal ini berkaitan dengan kondisi fisikologis yang secara tidak disengaja dirasakan oleh anak khususnya perempuan pada masa tumbuh kembangnya.

Hal ini sejalan dengan penelitian yang dilakukan oleh Rahayu (2015) dengan dibuktikan dari hasil analisis statistik (Kendall Tau) didapatkan nilai signifikasi (p) sebesar 0,004 dengan nilai $\alpha=5 \%$, dimana nilai $\mathrm{p}<0,05$ sehingga Ho ditolak Ha diterima, artinya ada hubungan antara status sosial ekonomi dengan usia menarche di SD Muhammadiyah Pakel Program Plus Yogyakarta. ${ }^{4}$ Namun penelitian tersebut tidak sejalan dengan penelitian yang dilakukan oleh Rochma (2013) yang menyatakan bahwa kejadian menarche tidak mempunyai hubungan yang bermakna dengan status sosial ekonomi keluarga di SMP Muhammdiyah 3 Yongyakarta dimana nilai $\mathrm{p}<0,05$ sehingga $\mathrm{Ho}$ diterima $\mathrm{Ha}$ ditolak. $^{7}$

Berdasarkan hasil penelitian yang diperoleh maka ditemukan adanya pengaruh yang signifikan antara faktor status gizi terhadap early menarche pada siswi sekolah dasar. Hal ini dapat dilihat berdasarkan hasil 
uji Chi Kuadrat pada Tabel.12, diperoleh nilai $\mathrm{X}^{2}$ hitung $=8,780$ dan $\quad \mathrm{X}^{2}$ tabel $=$ 5,991 dengan taraf signifikan 5\%. Karena $X^{2}$ hitung $>X^{2}$ tabel, ini berarti Ha diterima dan Ho ditolak. Artinya ada pengaruh yang signifikan antara status gizi terhadap siswi sekolah dasar yang mengalami early menarche.

Berdasarkan dari hasil penelitian menunjukkan bahwa keadaan status gizi yang normal dan keadaan status gizi yang tidak normal atau obesitas itu mempengaruhi terjadinya erlay menarche karena asupan gizi yang kurang menyebabkan gizi pada seseorang akan berdampak pada penurunan fungsi reproduksi. Status gizi anak wanita akan sangat mempengaruhi terjadinya erlay menarche baik dari faktor kejadian menarche, dari hasil wawancara langsung pada responden menyatakan bahwa biasa terjadi keluhan-keluhan selama menarche seperti adanya rasa nyeri, perutnya terasa pegal dan kurang nyaman tetapi ada juga yang tidak merasakan keluhan tersebut itu semua karena asupan gizi yang edukat (berpendidikan). Gizi kurang atau terbatas akan mempengaruhi fungsi organ tubuh yang akan menyebabkan terganggunya fungsi reproduksi, hal ini mengakibatkan gangguan pada haid, tetapi akan berangsur baik bila asupan makanan yang bernutrisi baik. Pada penelitian tersebut adapula yang obesitas mengalami erlay menarche sebanyak $8,2 \%$ tentu saja ini berasal dari makanan yang bergizi dan berlemak tinggi dan bersal dari hewani akan mengakibatkan pertumbuhan berat badan pada perempuan dimana dapat mempengaruhi pembentukan hormon -hormon yang mempengaruhi datangnya erlay menarche. Sehingga dengan perbaikan gizi atau asupan gizi yang baik dapat menyebabkan umur haid pertama menjadi lebih dini.

Usia menarche sangat bervariasi dan sangat tergantung pada status gizi dan pada penelitian tersebut keadaan status gizi siswi sebagian besar normal sebanyak 72,1 \% sebagian dari mereka juga ada yang menglami obestitas sebanyak $8,2 \%$ padahal pada umumnya anak perempuan yang lebih tinggi dan lebih berat dengan massa lemak tubuh yang lebih besar cenderung mencapai menarche diusia muda. Faktor ukuran tubuh termaksud tinggi, berat badan, indeks massa tubuh dan persentase lemak tubuh lama dibuktikan berasosiasi kuat dengan mulainya menarche.

Pada wanita anoreksia kadar hormon steroid mengalami perubahan yaitu meningkatnya kadar testoterone serum dan penurunan sekresi 17-keto sreroid dalam urine, diantaranya androsteron dan epioandrosteron, dampaknya terjadi perubahan siklus ovulasi yang mengakibatkan lamanya menarche. remaja yang memiliki status gizi tinggi akan mengalami menarche di usia yang lebih cepat dibanding mereka yang memiliki status gizi rendah, karena perbedaan jumlah kelenjar adiposa yang mereka punya menghasilkan jumlah sekresi kadar leptin yang berbeda. Mereka yang memiliki status 
gizi tinggi atau di atas normal akan mendapat menarche di usia yang terlalu cepat, sedangkan mereka yang memiliki status gizi rendah atau di bawah normal mengalami menarche di usia yang terlalu lambat. Lalu, mereka dengan status gizi yang normal mengalami menarche di usia yang juga normal. Peristiwa menarhe sangat erat hubungannya dengan masa puncak kurva kecepatan penambahan tinggi badan. Masa ini ditentukan oleh berbagai faktor, tetapi yang terpenting adalah faktor genetik. Sangat erat hubungan antara umur menarhe ibu dengan putrinya, dan lebih erat lagi antar umur menarhe perempuan bersaudara. Faktor lain yang berperan penting adalah status gizi, gadis gemuk akan mendapat menarhe lebih awal daripada yang kurus. Semua penyakit kronik yang menggangu status gizi atau oksigenasi jaringan akan memperlambat pola maturasi pubertas, terutama waktu menarche.

Penelitian ini sejalan dengan penelitian yang dilakukan oleh Eni Petraningsi (2012) di Yogyakarta dengan hasil analisis dengan Uji Chi Square diperoleh nilai siqnifikan $0,000(\mathrm{p}<0,05)$ nilai $X^{2}$ hitung sebesar 20,786 dengan nilai $\mathrm{X}^{2}$ tabel untuk df=2 adalah sebesar 5,591. Dari hasil tersebut diketahui bahwa $\mathrm{X}^{2}$ hitung $>X^{2}$ tabel sehingga dapat disimpulkan bahwa ada hubungan antara umur menarche dengan status gizi. ${ }^{8}$ Namun penelitian tersebut tidak sejalan dengan penelitian yang dilakukan oleh Ayuningtyas
(2013) mengenai hubungan status gizi dengan usia menarche pada siswi SMP Negeri 1 Jember dimana didapatkan hasil tidak ada hubungan antara status gizi dengan kejadian menarche, karena pada tempat penelitianyang dilakukan oleh Ayuningtyas bahwa usia menarche responden lebih cenderung dipengaruhi oleh faktor-faktor yang lainnya seperti faktor lingkungan dan faktor genetik. $^{8}$

\section{KESIMPULAN DAN SARAN}

Dari hasil penelitian dan pembahasan yang dilakukan mengenai ada pengaruh atau tidak ada pengaruh faktor lingkungan terhadap siswi sekolah dasar yang mengalami early menarche di Kelurahan Lapadde Kota Parepare, Ada pengaruh faktor lingkungan, status ekonomi keluarga dan status gizi terhadap early menarche pada siswi sekolah dasar di Kelurahan Lapadde Kota Parepare. Berdasarkan penelitian yang telah dilakukan oleh penulis, maka dipandang perlu mengajukan saran yaitu diharapkan penelitian ini dapat dijadikan sebagai pengalaman dalam melakukan penelitian, serta sebagai acuan untuk melakukan penelitian selanjutnya pada jenjang yang lebih tinggi, diharapkan hasil penelitian ini dapat dimanfaatkan untuk memperoleh informasi baru mengenai kondisi kesehatan reproduksi siswa, khususnya tentang menarche, dan beberapa faktor yang mempengaruhinya. Dan Manfaat diharapakan dapat meningkatkan 
pengetahuan remaja putri mengenai menarche sehingga akan lebih siap dalam menghadapi menstruasi pertamanya dan bagi penelitian selanjutnya Hasil penelitian ini dapat digunakan sebagai perbandingan dan dapat dikembangkan lagi untuk penelitian berikutnya yang berhubungan dengan

\section{DAFTAR PUSTAKA}

1. Al-Mighwar, Muhammad. Psikologi Remaja. Bandung: Pustaka Setia; 2011.

2. Atikah P. Menarche menstruasi pertama penuh makna. Yogyakarta: Nuha Medika; 2012.

3. Indah S. Menarche. Yokyakarta : Mulia Medika; 2015.

4. Rahayu. Hubungan antara status sosial ekonomi dengan usia Menarche di SD Muhammadiyah Pakel Program Plus Yokyakarta: Yokyakarta; 2015.

5. Beddu S. Faktor-Faktor yang Berhubungan dengan Status Gizi dan Usia; 2013. kecemasan menghadapi menarche, hasil penelitian ini diharapkan dapat menciptakan sebuah kegiatan khusus seperti bimbingan konseling atau keputrian dimana siswi dan guru dapat saling berbagi informasi dan pengetahuan mengenai menarche dan menstruasi.

6. Wulandari P. Hubungan gaya hidup dan status gizi dengan kejadian Menarche di SMPN 31 Semarang: Semarang; 2015.

7. Petraningsi, Eni. Hubungan Antara Umur Menarche dengan Status Gizi di SMP 20 Negeri . Yokyakarta: Yokyakarta; 2012.

8. Ayuningtyas. Analisis Hubungan Status Gizi dan Gaya Hidup Dengan Usia Menarche Pada Siswi SMP Negeri 1 Jember. Jamber; 2013.

9. Usman. Analisis Kinerja Tenaga Kesehatan pada Puskesmas Lapadde Kota Parepare. 2016; Media Kesehatan Masyarakat Indonesia: 12(1): 21-28. 


\section{LAMPIRAN}

Tabel 1. Distribusi responden berdasarkan umur pada sisiwi sekolah dasar di Kelurahan Lapadde Kota Parepare

Distribusi responden berdasarkan Umur

Frekuensi (f)

Persentase $(\%)$

\begin{tabular}{ccc}
\hline $9-11$ Tahun & 23 & 37,7 \\
$11-13$ Tahun & 38 & 62,3 \\
\hline Total & 61 & 100 \\
\hline
\end{tabular}

Tabel 2. Pengaruh faktor lingkungan terhadap early menarche pada siswi sekolah dasar di Kelurahan Lapadde Kota Parepare.

\begin{tabular}{|c|c|c|c|c|c|c|c|}
\hline \multirow{3}{*}{ Faktor lingkungan } & \multicolumn{4}{|c|}{ Early menarche } & \multirow{2}{*}{\multicolumn{2}{|c|}{ Total }} & \multirow{3}{*}{$P$} \\
\hline & \multicolumn{2}{|c|}{ Cepat } & \multicolumn{2}{|c|}{ Lambat } & & & \\
\hline & $\mathrm{n}$ & $\%$ & $\mathrm{n}$ & $\%$ & $\mathrm{n}$ & $\%$ & \\
\hline Berpengaruh & 21 & 34,4 & 4 & 6,6 & 25 & 41 & \\
\hline Tidak berpengaruh & 3 & 4,9 & 33 & 54,1 & 36 & 59 & 35,397 \\
\hline Total & 24 & 39,3 & 37 & 60,7 & 61 & 100 & \\
\hline
\end{tabular}

Tabel 3. Pengaruh status ekonomi terhadap early menarche pada siswi sekolah dasar di Kelurahan Lapadde Kota Parepare

\begin{tabular}{clccccccc}
\hline \multirow{3}{*}{ Status ekonomi } & \multicolumn{4}{c}{ Early menarche } & \multicolumn{2}{c}{ Total } & \multirow{2}{*}{$P$} \\
\cline { 2 - 6 } & \multicolumn{3}{c}{ Cepat } & \multicolumn{3}{c}{ Lambat } & & \\
\cline { 2 - 7 } & $\mathrm{n}$ & $\%$ & $\mathrm{n}$ & $\%$ & $\mathrm{n}$ & $\%$ & \\
\hline Tinggi & 3 & 5 & 6 & 9,8 & 9 & 14,8 & \\
Sedang & 8 & 13 & 30 & 49,2 & 38 & 62,2 & \multirow{2}{*}{22,263} \\
Rendah & 13 & 21,3 & 1 & 1,7 & 14 & 23 & \\
\hline Total & 24 & 39,3 & 37 & 60,7 & 61 & 100 & \\
\hline
\end{tabular}

Tabel 4. Pengaruh status gizi terhadap early menarche pada siswi sekolah dasar di Kelurahan Lapadde Kota ParePare.

\begin{tabular}{clclcccc}
\hline & \multicolumn{4}{c}{ Early menarche } & \multirow{2}{*}{ Total } & \multirow{2}{*}{$P$} \\
\cline { 2 - 5 } Status gizi & \multicolumn{2}{c}{ Cepat } & \multicolumn{2}{c}{ Lambat } & & \\
\cline { 2 - 6 } & $\mathrm{n}$ & $\%$ & $\mathrm{n}$ & $\%$ & $\mathrm{n}$ & $\%$ & \\
\hline Kurus & 5 & 8,20 & 7 & 11,5 & 12 & 19,7 \\
Normal & 14 & 22,9 & 30 & 49,2 & 44 & 72,1 & \\
Obesitas & 5 & 8,20 & 0 & 0 & 5 & 8,20 & 8,780 \\
\hline Total & 24 & 39,3 & 37 & 60,7 & 61 & 100 & \\
\hline
\end{tabular}

